Thelence

\title{
From Finances to Transnational Mobility: Searching for the Global Jihadists' Achilles Heel
}

\section{Ersel Aydinli}

To cite this article: Ersel Aydinli (2006) From Finances to Transnational Mobility: Searching for the Global Jihadists' Achilles Heel, Terrorism and Political Violence, 18:2, 301-313, DOI: 10.1080/09546550600570135

To link to this article: https://doi.org/10.1080/09546550600570135

曲 Published online: 25 Jan 2007.

Submit your article to this journal $\pi$

LII Article views: 314

Citing articles: 2 View citing articles $\sqsubset$ 


\title{
From Finances to Transnational Mobility: Searching for the Global Jihadists' Achilles Heel
}

\author{
ERSEL AYDINLI \\ George Washington University, Elliott School of International Affairs, \\ Washington, DC, USA
}

\begin{abstract}
This article seeks to uncover a primary source of vulnerability in the global Jihadist terrorist network. It offers a critical examination of the traditional money lead for countering global Jihadist terrorism, and concludes that in this case, it is not the most effective method. Rather, the concept of transnational mobility, both as it relates to socialization into and professionalization within the Jihadist network, is identified as the lifeblood of the network, and thus an arguably more appropriate focus for countering strategies. Issues surrounding travel document security are analysed within an overarching dichotomous framework of offensive/defensive counterterrorism strategies, emphasizing the need for active penetration by intelligence forces into the terrorist networks and relevant mobility-related realms.
\end{abstract}

Keywords terrorism, transitional mobility, Jihadist, finance, travel documents, intelligence, countering terrorism

\section{The Money Lead}

Since the 1980s in particular, when the "money lead" came to be emphasized in the struggle against international drug cartels, police and financial crimes experts have spent tremendous time and energy honing their skills to undermine the financial support systems of criminal organizations. Though the argument and practice of applying similar methods in the fight against terrorist groups has also long existed, ${ }^{1}$ the real push for such an approach came after $9 / 11 .^{2}$ In the desperate search for an effective response during the chaotic and traumatic atmosphere following the attacks, the natural inclination was to fall back on standard operating procedures, and in this case the structure, mechanisms, and strategies of the money lead were well established. The huge volume of media coverage of the Bush administration's vow to go after the terrorists' money not only documents the fact that the money lead strategy almost immediately became a priority in Washington, but also attests to the popular belief that such an approach was tried and true, and could therefore provide a guiding light in the daunting new counter-terrorism struggle.

The arguments seemed convincing. A "follow the money" approach could arguably provide not only preventive measures against future attacks by, for example, freezing a group's assets, but even more importantly, could allow counter-terror forces access to parts of the network hidden behind its visible figureheads. It also appeared to present a relatively easy strategy to employ because,

Address correspondence to Ersel Aydinli, Department of International Relations, Bilkent University, Ankara, Turkey, 06800. E-mail: aydinli@bilkent.edu.tr 
as noted above, it could draw upon existing legislative, regulatory, and policing mechanisms. Ultimately, since it was presumed that terrorists could accomplish little without money, it seemed logical that successfully tracking down their money routes would enable counter-terrorism forces to slow down or put an end to their activities.

But not only were the targets in this case no longer traditional money launderers, drug smugglers, or other such criminal groups, they were not even "traditional" terrorists. Today's Jihadist ${ }^{3}$ terror network represents something new among terrorist organizations, ${ }^{4}$ and the argument can be made that with this new target, following the money is not a particularly effective strategy. Indeed, some research over the last few years has begun to question whether so-called "finance warfare" has been an appropriate strategy. ${ }^{5}$ While these studies concede that there are great challenges to the approach, and most propose ways of improving its tactics and methods, none has asked whether inherent differences in the nature and operation of this terrorist target might justify setting new priorities for current countering efforts. If such differences exist, what might they be, and what clues might they provide for conducting a more effective "war on terrorism"?

\section{Jihadist Finances}

At the heart of the problem seems to be the observation that in the Jihadist terrorist network, money plays a role different from what counter-terror finance experts have come to expect. Traditionally, terrorist groups have tended to view money-making as an essential collective effort, with local cells actively participating in such activities as drug trafficking, robberies, or mob-related activities, to raise funds for the group's operational costs. Not only do such money-making endeavors become an integral part of the group's activities, but such a comprehensive system generally leads to established methods and routes of circulation for the resulting money. As a consequence, there are both greater opportunities for counter-terrorists to track down the money, and often significant results when they do.

In the case of the Jihadist terrorist network, however, it is often much more difficult to follow the money. The first problem is that within this network, funds do not always travel in the expected ways or through the familiar financial channels, such as wire transfers, large deposits of assets, or even credit card expenditures, all of which can be traced. The Jihadist network has different, ad hoc, and often seemingly archaic systems, to make their necessary money transfers. The most often referred to of these in the wake of the 9/11 attacks is the hawala system, which involves the transfer of funds via an informal association of hawaladars, or individuals on either end who accept or pay out the requested funds. ${ }^{6}$ An alternative is the Selaam system, which basically involves the dispatching of someone to deliver regards or greetings from one person to another, with an accompanying request for money. Though generally an explanation of the exact purpose for the request is not given, there is an understanding that it will be used for the spread of Islam (tabligh), or that it is connected with the traditional Islamic duty of giving alms (zekat). The attaching of the financial request to an extension of greetings is basically all that is needed to conduct the "transfer." Because this traditional system is widespread among the global Muslim communities, it is difficult to determine whether any particular exchange is in support of terrorist activities or is for normal communal or personal reasons. 
Whatever name is given, these methods generally rely on systems outside of traditional banking transfers, and in many cases depend on human travelers or couriers physically carrying the money from one place to another. These systems are therefore "humanized," in the sense that they are removed from more technically sophisticated methods of transfer. In these crucial ways, the Jihadist terrorists' methods are not necessarily like those of drug dealers or other more familiar transnational criminals, and are thus not as conducive to traditional means of tracing.

A second reason why a follow the money approach will have problems is that there is a continuing popular misperception of bin Laden and, subsequently, Al Qaeda, as being financially limitless, handing out money liberally for the Jihadist terrorist cause. Thus, perhaps even more important than possible procedural inadequacies of a follow the money strategy, is the underlying myth that the Jihadist network is managing and employing immense amounts of money. Yes, they use money, but money is not a key factor making the network's activities possible.

Looking at actual costs of attacks, it has been shown that even major ones like 9/11 were conducted for a full cost of less than $\$ 500,000$, and smaller, but still significant attacks for far less. ${ }^{7}$ In the case of the 2003 Istanbul bombings, total financing costs have been estimated at around $\$ 75,000 .{ }^{8}$ Costs are kept low both through the methods used and the general frugality of the terrorists. Reports on the $9 / 11$ bombings have shown for example how the bombers rented inexpensive cars, stayed in low-cost hotels, and used coin-operated laundry machines. Similarly, police reports on the Istanbul bombings describe how the money for the attacks was held by one or two key figures, who doled it out quite sparingly, forbidding, for example, such luxuries as using taxis rather than public transport for daily business. It is also interesting to note that the Jihadist network may not have the burden, as do some other terrorist organizations, of providing financial support for the families of suicide bombers. ${ }^{9}$ Also in the police reports from the Istanbul bombings was a statement by the wife of one of the attackers that when she asked her husband who would look after her and the children after the attack, he replied that "Allah" would. ${ }^{10}$ The same police report also confirms that this particular woman, lacking professional training or financial assistance from the network, did indeed go back to live with her parents after the bombings.

Interestingly, this overall sparing use of money is in part made possible by certain religious understandings of the Jihadists, among whom it is generally considered immoral to waste funds, as if by doing so, one would be stealing from fellow Muslims. The overall lack of excess money, combined with a Jihadist sense of the immorality of extravagance, leads to extreme efficiency in the use of whatever funds are available. In a sense, people are forced into doing the most with the least amount of money. Jihadist morality reminds its followers that the original Jihadists at the time of the prophet were people without resources, and since the current Jihadists seek to repeat the ways of their predecessors, they are also interested in adopting this aspect. The overall attitude towards money is captured in a phrase often cited in the texts of Turkish Jihadists: "Bir lokma, bir hirka" —one bite of food, one piece of clothing. It is also illustrated in the works of the famous Jihadist figure, Dr. Abdullah Azzam. Azzam spoke extensively about how even eating "luxurious" food has the potential to corrupt: "their stomachs," he said, "are full of well cooked chicken and rice, so they forget their purpose for being in the land of Jihad." 11 Noteworthy is the idea that the standard for well-being is associated here with such an arguably simple item as a chicken, and the 
accusatory finger subsequently pointed at those who would seek such foods over simpler menus of perhaps bread and basic vegetables. For those individuals who opt to store any extra wealth rather than contribute it to the cause of expanding the Muslim nation, Azzam was equally harsh. He referred repeatedly to articles of the Tevbe verse, in which the gold or silver one saves for oneself, becomes "knives and swords in their chests on Judgement Day."12

Ultimately, whether one considers the often untraceable means used by the Jihadists for moving money around, the relatively small amounts of money this network has shown it requires to carry out significant attacks, or the social attitudes among Jihadists towards frugality, it is evident that money does not play the critical role for the Jihadists that it may play for other terrorist groups. Therefore, the "money lead" approach - though surely it has some role in current counter-terrorism efforts-does not warrant being given priority.

\section{Transnational Mobility}

If money circulation is not the key to unraveling the network, then what is? What is it that this network needs even more than money? And how can counter-terror strategists take advantage of this need to improve their ability to fight against this network? Let's first consider two intertwined aspects of the Jihadist terrorist phenomenon: the transnational nature of the Jihadist struggle and the Jihadists themselves.

In the late 1980s, the leadership of the Jihadist movement went through debates, similar to those that once raged among Communist leaders of the twentieth century's great global ideological challenge for world domination. The debates evolved around whether the group's struggle should be concentrated in a single country (and later expand outwards from there) or whether it should take place simultaneously around the world. As the Soviets withdrew from Afghanistan, discussions on this topic between the "single country" advocate, Azzam, and the multiple front supporters, Osama bin Laden and Ayman al Zawahiri, ended in Azzam's execution and a shift towards the latter position. ${ }^{13}$ The strengthening of the idea of global struggle necessitated a transnational organization of the Jihadist network, unlike that of the more common territorially-fixed terrorist organizations, which are usually located in single countries. The network's need to become transnational then became all that much more urgent when Al Qaeda was forced to desert Afghanistan in the face of U.S. attacks, and flee abroad in a dispersed manner. ${ }^{14}$ The upshot is that the Jihadist terror network has become largely transnational in nature, and as such is reliant on transnational mobility.

Turning to the Jihadists themselves, one outstanding characteristic among them is that they are a group of individuals who are present in today's world, but who strongly believe that they are reliving a struggle that occurred at the time of the prophet Mohammed, during the expanding years of Islam. In other words, Jihadists are socialized from early on to interpret today's political conditions and daily challenges according to references (both religious and anecdotal) of roughly 1,400 years ago. In a sense, time, space, and history become integrated, to form the holistic reality in which the Jihadists present the mission, challenges, and prescriptions for a global Muslim nation. A key aspect of this integration, one discussed in more detail in the following section, is the understanding that the Prophet's own migration to Medina in order to save the faith, becomes a blueprint for today's Jihadists. Perhaps the best 
indication of the centrality of mobility for the Jihadist movement is therefore reflected in the Jihadist slogan, "faith-hijra (migration) - jihad-Ummah (global Muslim community)," in other words, the initiation into Jihadism begins with an act of physical movement, or mobility. ${ }^{15}$

Thus both the retrospective vision of Jihadists and the global organizational nature of their movement reveal an extreme need for transnational mobility, ${ }^{16}$ a need so strong that it may present a better alternative to the counter-terror forces' emphasis on the money lead. Mobility emerges as essential for the Jihadists at more concrete levels as well. When you look for example at their recruitment patterns or at how individuals come to join Jihadist terrorist activity, one frequently finds a connection to mobility. A traditional pathway to becoming a Jihadist was by travelling to the jihad lands, such as Afghanistan, while another came about when individuals were students travelling to the West for further education. Yet another pathway for some was through normal migration to the West for economic purposes. The common point in these pathways to joining the Jihadists and ultimately contributing to the formation of what can now be spoken of as a global Jihadist network, is that they involve travelling, in other words, mobility. ${ }^{17}$

\section{Mobility and Socialization}

Two stages in the evolution of a Jihadist exemplify the absolute need for mobility among network members. The first is what could be labeled as mobility required by initial socialization. Even before an individual becomes an active member of the Jihadist network, he may begin to interpret his place in the world according to the religious teachings of the Koran, and in particular, the verses focusing on the early days of the first Muslims. If he too senses himself isolated from the world around him, as being surrounded by non-Muslims or imperfect ones, he may come to view the world dichotomously, as early Muslims did-as the dar al Islam (abode of Islam) and the dar al harb (house of war, or the home of the of kufr, or infidel, where Islam is denied or rejected). The moment this person defines his local environment as part of the dar al harb, it is often the case that he feels he must follow the practice of the early Muslims, who left the land of the Mushrik (idolater and polytheist) in Mecca and migrated to Medina. He too must migrate (make hijra) to the land of Islam. ${ }^{18}$ In the case of the Istanbul bombers, years before the bombings, they had openly rejected what they saw as the non-Islamic lifestyle being led by most Turks, and expressed what they saw as their obligation to migrate to a land where they could live and fight for true Islam. ${ }^{19}$ For them, and many others in the 1980 s, this place was Afghanistan. Later, Chechnya, Bosnia, Kashmir, and nowadays Iraq and once again perhaps Afghanistan, constitute primary destinations for those seeking a land where they can fight against non-believers for a true Islamic ideal.

Interestingly, even the recent examples of "home-grown" terrorism among the diaspora communities in Europe - namely, the July 2005 London bombings - and the possibility that future threats may increasingly come from this type of terrorism, do not diminish the importance of mobility, particularly at the level of initial and continuing socialization into Jihadist circles. The diaspora-based Jihadist communities may not be as local as they appear, as members of these circles still tend to travel, often to their homelands, both for business and personal reasons, and quite often for purposes of finding marriage partners with appropriate worldviews. ${ }^{20}$ 


\section{Mobility, Professionalization, and the Role of the Connectors}

For the individual who has become an active part of the network, a second stage of mobility may start - a mobility required by professionalization within the Jihadist community. If an individual becomes an operative, he will require a more sophisticated form of mobility in order to reach transnational destinations and carry out both legal and illegal network-related activities. If, for example, the individual is involved in the network's financial system (e.g., sending money with couriers), he will need to be able to travel easily across borders. Naturally if individuals are traveling abroad to "Jihad" lands, they will need mobility to get there, but even while there, mobility needs may arise in ways one may not expect. According to Azzam's speeches and writings from the days of the war in Afghanistan, and likely relevant now to foreign Jihadists fighting in Iraq, every Jihadist fighting abroad has the right — and indeed, duty - to return home for a period of time each year, in order to spend time with his family, and communicate the cause to others (recruitment). For unmarried Jihadists, Azzam prescribed two months "holiday," to "eat well" and "refresh" oneself. For those who are married, he allowed for one and one-half month breaks at least twice annually. ${ }^{21}$

Mobility is of course most crucial for those operatives whose job is to serve as connectors between the core of the network and the outlying "sleeping" cells around the globe. These connector figures became key elements in the organization of the Jihadist network after it was kicked out of Afghanistan post-9/11, and forced into a kind of "transnational exile." Contrary to expectations and hopes, the network proved adept at reorganizing itself and adapting to the transnational environment, and in fact continued to carry out successful attacks - though many were lower profile ones than the 2001 attacks in the U.S. ${ }^{22}$ Although local cells played the crucial roles in actually carrying out the post-9/11 attacks in, for example, Istanbul, Bali, Casablanca, and Madrid, in each case there was generally a connector figure, who brought in the necessary know-how, leadership skills, money, and guidance from the Al Qaeda leadership, to help recruit and build up these seemingly homegrown cells.

This practice of having a connector was not entirely new to Al Qaeda; in fact, the $9 / 11$ attacks themselves were largely made possible due to the contributions of a similar "connector" to coordinate the operation. Khalid Sheikh Mohammed was the "chief manager" of the $9 / 11$ plot. ${ }^{23}$ The $9 / 11$ report goes on to suggest that without his imagination, technical aptitude, and managerial skills, the 9/11 attacks would probably not have occurred - or at least not on the scale that they did. More importantly, if Khalid Sheikh Mohammed had not had access to a great mobility across continents and between countries, traveling to the U.S.A., Pakistan, Afghanistan, Qatar, the Philippines, Sudan, Yemen, Malaysia, Brazil, Iran, and Indonesia, he would not have been able to cultivate transnational relationships, to recruit and build up local cells, to transmit orders, and ultimately to pull together the transnational operation that resulted in the $9 / 11$ attacks.

Yet another mobile connector was Karim Majjati. A former medical student from Morocco, Majjati was responsible for organizing the group that blew up three residential compounds in Riyadh in May 2003. Just one week later and 3,000 miles away, another group he had organized and helped, pulled off the deadliest suicide attacks in Moroccan history, the Casablanca bombings, which killed forty-five people. Majjati, who was killed by accident in a shootout in April 2005 in Saudi Arabia, was both extremely mobile and a master of avoiding attention when 
traveling between countries thanks to his language abilities and multiple passports. Although he traveled so extensively that a neighbor reported seeing him only twice in the three years after the 9/11 attacks, an anonymous security official admits that they had "no tangible evidence where he was." 24

It is also now known that the network's November 2003 bombings in Istanbul would probably not have been accomplished if it were not for a connector figure who had the clear plans in mind, the necessary know-how, and the (albeit not substantial) financial backing. ${ }^{25}$ In this case, the connector was Habib Aktas, a Turkish citizen of Arab origin. Court documents and police reports reveal certain characteristics about Aktas, which no doubt helped to make him an important example of these crucial connector figures, namely, his highly developed computer skills, linguistic skills (Arabic, English, and Turkish), vast religious knowledge, reported charisma, actual experience "in the field" in Afghanistan and, of course, being in possession of means, which permitted him mobility. It was his frequent travels throughout the Middle East, and back and forth to Turkey, which enabled him to build up the Istanbul cell and equip it in every sense from ideology to motivation to technology, to prepare for the bombings. ${ }^{26}$ Aktas reportedly continued to travel after the attacks, but is now believed to have been killed in Iraq in spring 2005.

The question then arises, what can be done to monitor mobility? Clearly, passports and other travel documents present the most concrete manifestations of mobility, and thus are vital to the Jihadist terrorist network. Passports and other travel documents were so crucial to Al Qaeda's operations even prior to the 9/11 attacks, that the organization operated an office of passports at the Kandahar Airport in Afghanistan, in which they altered papers, including passports, visas, and identification cards. $^{27}$

If mobility is accepted as essential for successful operation of the Jihadist terrorist network, and travel documents are clearly the key tools with which states can monitor such transnational mobility, it is essential to seek ways of coping with the dilemma that these key tools can be forged and manipulated-and unfortunately, adequate attention has not yet been paid to this issue. ${ }^{28}$ Terrorists are of course quick to master forgery and manipulation techniques, ${ }^{29}$ and to re-adapt when countering measures are taken-making an over-reliance on any one countering technique or technology a mistake. The following section provides an actual account of how travel documents have been manipulated. The hope is that through detailing particular cases like this, there is the possibility to better understand the overall issue of travel document security and thus support better countering measures.

\section{Forgery Tales and Mobility}

Post-event investigations in the case of the Istanbul bombings were very successful. ${ }^{30}$ Within just a couple of weeks, the details of how the attacks were prepared as well as the names and histories of the perpetrators had all been uncovered. The crucial clues came when police graphologists were able to connect the handwriting on a receipt found at the crime scene with the writing on a passport application, and thus track down the person's photograph. With this, the police uncovered the true identity of a key operative, who was subsequently arrested at the Iranian border. In the Istanbul bombings case, the need for mobility proved to be the terrorists' Achilles heel.

It is clear that transnational mobility requires traveling documents-legal, or more commonly, illegal ones. In Turkey, these precious papers are the most 
frequently found items in police raids on Jihadists' quarters, and multiple passports - often Turkish but also from other countries such as Morocco, Algeria, or Pakistan-are often confiscated from individuals arrested while crossing Turkish borders. Due to the high volume of illegal migration through Istanbul to Europe, the city on the Bosphorus has become a veritable passport capital. With passports being stolen, sold, handed from person to person in the quest to obtain (by whatever means possible) a visa to the West, and various other tactics for obtaining legal documents in other peoples' names, it becomes disturbingly obvious that obtaining illegal travel documents is not as difficult as one might expect.

According to Turkish intelligence sources, when terrorists want to obtain false travel documents, two primary routes exist. First, they can turn to the established forged travel document industry, which serves a wide audience, from individuals seeking documents to travel and find work, to mafia criminals and drug traffickers, to terrorists. People in the industry collect passports, generally by stealing or purchasing them, and then replace the original photos with those of the people who wish to use them.

An alternative technique for acquiring travel documents, one that was used by individuals involved in the Istanbul bombings, requires the help of a local person - often a friend or relative. This person is asked to go to his town manager (muhtar) and request a paper showing that he has lost his ID. The operative needing the passport then takes that paper and goes to the regional census office to request a new ID. Since there are no photographs on birth documents, and since the census office only wires or telephones for confirmation about the original records, the second person is able to pretend to be the first by simply providing the muhtar's paper and showing his own photo. The center then issues a new ID, which is genuine, except for the photo. The perpetrators generally choose to adopt the IDs of relatives or friends who come from small districts and who are not likely to leave those districts, so the chance of accidental discovery is minimal. Moreover, since the information on the ID generally is "clean," that is, it belongs to a law-abiding citizen, the subsequent application process to the police for a passport is likely to pass easily. Within days, the criminal is able to obtain a fully legal and real passport, in someone else's name, but with his own photo in it. Recent reforms and developments in policing services in Turkey have made it possible to apply for a passport online, making the process even more vulnerable to such forgery attempts. On the other hand, the technique is not necessarily an easy one to carry out, in that it relies on trusting relationships between the operatives and the individuals whose identities are being "borrowed."

Combating these two primary methods of obtaining false travel documents requires different approaches. For the latter method, the only sure way is to strengthen the procedures used by local government offices. This would have to involve more stringent methods of double-checking between offices as well as reforming birth records to include a verifiable means of identification, such as pictures or possibly even fingerprints.

Current counter-terrorism efforts to confront the larger illegal travel document industry suffer from problems both at the local and global levels. In the Turkish example, policing of travel document fraud at the local level is hampered by bureaucratic politics in which tasks are often ineffectively divided between various departments. Depending on the victim or on the suspected user of the travel documents, cases may be handled by departments as diverse as tourism/foreigners, small crimes, organized crime, narcotics, financial crimes, or counter-terrorism. At the global level, 
some states monitor travel document fraud better than others do. These policies result in inconsistencies in the recording and sharing of border control records. ${ }^{31}$

Yet mobility-related counter-terrorism strategies are discussed in a primarily defensive manner. In other words, when confronted with the problem of mobile terrorists (or other criminals), an almost instinctive response strategy is to go on the defensive - to build up better walls and border controls, and try to stop the illegal infiltration of people with bad intentions. ${ }^{32}$ While these types of defensive moves have a role to play, it is extremely important to understand the risks of an overly defensive positioning, and explore ways of alternative, "offensive" moves that can be taken in the effort to stem terrorists' mobility.

\section{The Pitfalls of Defensive Intelligence}

The 9/11 Report includes a wide variety of suggestions for ways to fight against terrorists, among which are methods such as the tracing of passports or increased surveillance of particular travel routes. However, the report looks at passports or travel patterns from a perspective of using them to defend homeland security, prevent future penetration, and thus future attacks. The understanding is a defensive one designed to stop the suspects at the border and send them back to where they've come from. It is reflective of a broad tendency towards defensive counter-terrorism strategies - a problem to which most countries succumb, as each tries to defend its own borders and territory.

A strategic over-reliance on defensive, border-protecting efforts is bound to fail in many cases. It is inadequate for effective counter-terrorism in developed countries, which have significant technological resources and personnel to protect their borders, and it may be downright dangerous when it is applied by countries with fewer resources. In such countries, the natural response when encountering suspicious individuals or activities within or at their borders, is often simply to expel the suspects without conducting full intelligence investigations. The result may be active or potential Jihadists who become part of a transnational soccer match where they are passed back and forth between different countries' intelligence agencies. This game means that little or no practical information about the Jihadists' political intentions are uncovered. These individuals eventually become known when they finally succeed in committing a real act. Some figures involved in the Istanbul bombings, for example, had been earlier rounded up in Georgia, which they had entered en route to Jihadist lands (Chechnya and Afghanistan). Although they were deemed suspicious by the Georgian police, they were simply brought back to the Turkish border and deposited there. ${ }^{33}$ Since the suspicions on the Georgian side were not shared (let alone investigations having been made) with the Turkish side, they were subsequently released by Turkish authorities.

Such examples are common because of the lack of consciousness for more offensive counter-terrorism strategies, and are exacerbated in many parts of the world due to the lack of resources. For Turkey and its neighboring countries, border authorities may lack actual holding cells for suspects. They are unlikely to have official funds with which to feed any individuals being held, or to have technological aids such as fax machines or computers, through which to share intelligence information. The problem is that a counter-terror struggle that relies on defensive tactics comes to resemble a crowded neighborhood in which everyone carefully sweeps the dirt from their houses into the street, without considering that there are no street cleaners. 


\section{Offensive Intelligence}

The undeniable significance of the current transnational terror threat, and the clear importance of mobility to transnational terrorists, mean that such uncoordinated, defensive-based efforts against travel document crimes can no longer be tolerated. This particular realm of criminal activity must be emphasized for the key role it may play in global security, and countered accordingly. Offensive measures involving the active penetration of human intelligence into the travel document industry, as well as of course the terrorist networks themselves, must be given priority on a global basis. Among the many benefits of such penetration into the former, would be to help out with sting operations, or with efforts to feed what could be called "bait" passports into the system. Obviously, direct human intelligence is also the only way to obtain direct information on suspicious passports or to obtain copies of the photos of the individuals intending to use these passports. Intelligence penetration of the laboratories which prepare the travel documents for terrorist organizations, could provide useful leads for tracing the mobility of members and their future activities. Most importantly, offensive efforts such as these to track and trace terrorists' travel documents and thus their transnational mobility could enable counter-terrorist forces to build up a database of the types of documents used, and to actually map out the terrorists' mobility patterns. By detecting such patterns, it would be possible to monitor the preparation stages of upcoming attacks and, eventually, to gain some kind of early warning capacity about future events.

The history of counter-terrorism around the globe teaches us that a defensive policy which focuses on building walls, either physical or psychological, almost always leaves the other side of the wall inadequately supervised and a fertile breeding ground for terrorist activities. It is in the nature of walls to first block your vision, to give you a false sense of security, and probably to compromise your ability to be truly engaged offensively.

While much of the Jihadist movement's efforts seem to have a concentrated focus these days in Iraq, this type of more traditional guerilla warfare will not remain the typical code of operation for the network. No matter what the outcome in Iraq, it is virtually inevitable that the global Jihadist network will at some point return with full energy to its operational modus vivendi of a terrorism based on transnational mobility. A constant offensive engagement with their key mobility procedures and apparatuses is the only way to have a degree of control over the war on terrorism. The Jihadists' great need for mobility and thus for travel documents, either genuine or forged, presents the most feasible Achilles heel for offensive counter-terrorist strategies.

\section{Notes}

1. For an early work suggesting the importance of the money lead in counter-terrorism efforts, see T. Sandler, J. T. Tschirhart, and J. Cauley, "A Theoretical Analysis of Transnational Terrorism," American Political Science Review 77 (1983): 36-54.

2. Fact Sheet on Terrorist Financing Executive Order, 24 September 2001, available at http:www.whitehouse.gov/news/releases/2001/09/print/20010924-2.htm.

3. It is important in a piece such as this to recognize at the outset the heterogeneity of the Muslim world and the many layers of Islamist activism within it. The word "jihad" refers to struggle. Depending on the particular discourse with which a Jihadist is indoctrinated, this struggle may be violent or non-violent (and neither group should be confused with other layers 
of the spectrum such as radical or political Islamists). The "Jihadists" referred to in this piece are those who are involved in a violent, armed struggle, and their active supporters.

4. For a few examples discussing such differences in terrorist groups as the organizational evolution from hierarchical to network structures, or from local to global operational capacity, see Isabelle Duyvesteyn, "How New is the New Terrorism?," Studies in Conflict and Terrorism 27, no. 5 (2004): 439-455; Paul Wilkinson, "Why Modern Terrorism? Differentiating Types and Distinguishing Ideological Motivations" in The New Global Terrorism: Characteristics, Causes, Control, Charles W. Kegley, Jr., ed. (New York: Prentice Hall, 2003), 106-138 and David Tucker, "What is New About the New Terrorism and How Dangerous Is It?," Terrorism and Political Violence 13, no. 3 (Autumn 2001): 1-14.

5. See recent works such as Martin S. Navias, "Finance Warfare as a Response to International Terrorism," The Political Quarterly (2002): 57-79; Peter Shields, "Finance Warfare, Surveillance and Collateral Damage," Peace Review, 16, no. 3 (September 2004): 357-364; Mark Basile, "Going to the Source: Why Al Qaeda's Financial Network is Likely to Withstand the Current War on Terrorist Financing," Studies in Conflict and Terrorism 27 (2004): 169-185; Valpy Fitzgerald, "Global Financial Information, Compliance Incentives and Terrorist Funding," European Journal of Political Economy 20 (2004): 387-401.

6. An interesting source for more information on the hawala system and the ways in which the war on terrorist financing has unjustly discredited this traditional money transfer system is Marieke de Goede's "Hawala Discourses and the War on Terrorist Finance," Environment and Planning D: Society and Space 21 (2003): 513-532.

7. For details on the costs of the 9/11 attacks see The 9/11 Commission Report, 1st edition (New York: W.W. Norton, 2004). For details on the costs of some other attacks and particularly good discussions of Al Qaeda's finances, see Rohan Gunaratna, Inside Al Qaeda: Global Network of Terror (New York: Columbia University Press, 2002), 60-70; and Roland Jacquard, In the Name of Osama bin Laden (Durham, NC: Duke University Press, 2002), ch. 11.

8. Contradictory amounts have been reported, including even one high estimate of around $\$ 150,000$ from an alleged accomplice. Since the actual individual who controlled all the finances is still at large, the exact amount cannot be known. However, given the very cautious spending habits of the perpetrators and the consistent numbers cited in the confession reports, a realistic assessment would be between $\$ 50-100,000$. These figures are based on an assessment of the known expenses - three minivans and the bomb-making materials - and the lack of costs for training, extensive travel, or support for the families.

9. Palestinian groups in particular, such as Hamas or Islamic Jihad, have been observed to have such systems in place. See Jessica Stern, Terror in the Name of God: Why Religious Militants Kill (New York: Harper Collins, 2003).

10. Saban Arslan and Devrim Tosunoglu, Dehset Scenaryosu: Istanbul'daki Intihar Saldirilarinin Icyuzu (Istanbul: Guncel Publishing, 2004), 212.

11. Dr. Abdullah Azzam, Tevbe Suresinin Golgesinde: Cihad Dersleri, vol. 2 [In the Shadow of the Tevbe Verse: Jihad Lessons] (Istanbul: Buruc Publishers, vols. 1 \& 2, 2nd ed., 1997), 382. Transcripts of Azzam's lectures have been translated into Turkish by an unofficial group called the "Turkish Translation Council," and are published by a printing house at which some of the individuals involved in the Istanbul bombings were employed.

12. Azzam (see note 11 above), vol. 1, 290.

13. Further details on these internal politics and new evolution can be found in Jason Burke, Al Qaeda: Casting a Shadow of Terror (I. B. Tauris, 2003).

14. Marc Sageman offers a nice graphic design of the organization's global expansion, reprinted in Terrence Henry, "Al Qaeda's Resurgence," Atlantic Monthly, June 2004, 5455. Henry's article also points to how successfully Al Qaeda has been adapting to a forced transnational exile.

15. Over the course of a series of panels and discussions at the Istanbul Conference on Democracy and Global Security, June 9-11, 2005, Istanbul, various practitioners referred to this slogan as the primary modus vivendi of the global Jihadist movement.

16. For a theoretical modeling of the centrality of mobility in the globalized era and systemic interpretations of mobility as a threat, see Ronen Shamir, "Without Borders: Notes on Globalization as a Mobility Regime," Sociological Theory, 23, no. 2 (June 2005): 197-215. 
17. Marc Sageman's book, Understanding Terrorist Networks, provides extensive data on the pre-9/11 Al Qaeda members, noting for example, that many were students abroad when they became radicalized. For details on the projected major source of future Jihadist terrorthe diaspora - see Olivier Roy, Globalized Islam: The Search for a New Ummah (New York: Columbia University Press, 2004).

18. Several suggestions for dealing with this alienation problem can be found in Umit Yurdakul, Police Chief in charge of counter-intelligence against Jihadists, "A Few Important Strategic Issues Related to Struggling Against Region-Motivated Terrorism-Radicalism," paper presented at the Istanbul Conference on Democracy and Global Security, June 9-11, 2005.

19. Prosecutor's Report, Istanbul State Security Court, February 25, 2004, 60.

20. For more on the increasing centrality of the diasporas and the implications on mobility, see Roy, Globalized Islam (See note 17 above).

21. Azzam (see note 11 above), vol. 2, 400.

22. A timeline of Al Qaeda attacks shows that the network carried out nearly twice as many attacks in the period after $9 / 11$ as it did in the five years before $9 / 11$. Henry (see note 14 above), 54.

23. The 9/11 Commission Report (see note 7 above), 145.

24. Cited in Craig Whitlock, "Odyssey of an Al Qaeda Operative: Moroccan's Trail of Terror Illustrates Ongoing Ability to Organize Attacks," Washington Post Foreign Service, 2 May 2005.

25. This assessment was made by a security official I interviewed (December 2004, Istanbul). The official was working on both the Istanbul bombings and on a case of an attempted attack by a local Jihadist group in which there had been no connector (and in which only the bombers were killed, and minimal damage was inflicted). In light of the two cases, it was his conclusion that without the professional help of someone "like Aktas," the local groups had little chance of carrying out a significant attack. In particular he noted that the type of explosives and the primitiveness of the target plan in the latter case were evidence of the lack of outside help.

26. His extensive travels are documented in both the Prosecutor's Report from the Istanbul State Security Court, and also in Arslan and Tosunoglu (see note 10 above).

27. The 9/11 Commission Report (see note 7 above), 169. The report also points out that $\mathrm{Al}$ Qaeda used outside facilitators, including fraudulent document vendors, travel agencies, and smugglers to help move operatives around the world.

28. It has been noted that there has not been a single major conference on international passport issues. Mark B. Salter, "Passports, Mobility, and Security: How Smart Can the Border Be?"' International Studies Perspectives 5, (2004): 71-91.

29. This includes, for example, the surprising numbers of stolen blank passports in usage, a reported 10 million currently in circulation according to Interpol, and reported in "A Review of the Use of Stolen Passports from Visa Waiver Countries to Enter the United States," Department of Homeland Security, Office of the Inspector General, Report OIG-05-07, December 2004. For more on travel document manipulation see T. Fuller, "EU Passports: An Easy-to-Steal Tool for Terrorists," International Herald Tribune, 8 January 2002; C. Kolker, "Fake Passports Touted as 'Legal Camouflage' for Travelers," Houston Chronicle, 28 December 1997; R. Russo, "Canadian Passports Easily Obtained," Canadian Press, 14 March 2001; P. J. Smith, "The Terrorists and Crime Bosses Behind the Fake Passport Trade," Jane's Intelligence Review 13 (2001): 42-44; O. Zill, "Crossing Borders: How Terrorists Use Fake Passports, Visas, and Other Identity Documents," Frontline, available online at www.pbs.org/wgbh/pages/frontline/shows/trail/etc/fake.html.

30. Unless otherwise specified, all details of the Istanbul bombing investigations and of the travel document trade in Turkey come from the Prosecutor's Report from the Istanbul bombings, police confession reports of suspected accomplices to the bombings, and from a series of interviews conducted in Istanbul and Ankara, with police and intelligence officers in April-May 2004 and between November 2004 and March 2005.

31. The Homeland Security Report on stolen passports (OIG-05-07, p. 7) notes that only 41 countries report their numbers of stolen passports to Interpol regularly, obviously weakening the agency's database for this information. 
32. As perhaps the ultimate expression of this defensive positioning there is the creation of the Department of Homeland Security, and the implication that it is here to secure us by building up layers of protection. If we look at the results and recommendations of the $9 / 11$ Commission Report in terms of mobility/passports, we see a primary emphasis on identifying what went wrong at the borders, the idea being that less porous (more defensive) borders are the key to securing the country. Even recent articles and news stories about travel freedoms seem to emphasize suggestions aimed at keeping the criminals outside our borders. See for example Sharon R. Reddick, "Point: The Case for Profiling," International Social Science Review 79, no. 3/4: 154-157; Philip Ross, "Passport to Nowhere," IEEE Spectrum (January 2005): 54-56; Frank Thomas, "US Asks for more data on travelers," USA Today, 4 May 2005.

33. Prosecutor's Report (see note 30 above). 